\title{
STRENGTH OF CONVENTIONAL AND DAMAGED REINFORCED CONCRETE BEAMS STRENGTHENED BY CARBON PLASTIC UNDER THE ACTION OF A SMALL LOAD OF HIGH LEVELS
}

\author{
${ }^{1}$ Antonova D. V., postgraduate, \\ antonova.dv@ukr.net, ORCID: 0000-0001-9021-857X \\ ${ }^{1}$ Karpiuk V. M., Doctor of Engineering, Professor, \\ v.karpiuk@ukr.net, ORCID: 0000-0002-4088-6489 \\ ${ }^{1}$ Odessa State Academy of Civil Engineering and Architecture \\ 4, Didrichson street, Odessa, 65029, Ukraine
}

\begin{abstract}
Most span reinforced concrete structures experience repeated loads of various sizes and signs, that is, a complex stress-strain state. During operation or during hostilities, span reinforced concrete structures experience significant damage and a significant decrease in bearing capacity, especially when a low-cycle repeated load is applied. In this regard, there is a need to restore their performance and/or to increase bearing capacity.

The current design standards do not contain recommendations for determining the residual bearing capacity of such structures and calculating their amplification. Known methods for restoring performance and strengthening the structure by increasing the cross section by attaching additional metal or reinforced concrete elements to them. But the methods for calculating this gain are also imperfect.

It is proposed to restore the operability of these structures by strengthening their stretched parts of the CFRP, and the experimental studies will form the basis for improving the deformation method for calculating their bearing capacity. Obviously, the main reason for the decrease in the bearing capacity of prototypes under low cycle alternating load is the violation of the structure of concrete, especially in the supporting areas, its softening and partial loss of adhesion to the reinforcement.

The greatest increase in residual deformations in concrete and transverse reinforcement of the research beams of the first and third series is observed in the first two to three cycles and, as a rule, they stabilize until the fifth or sixth cycle. And in some samples with a minimum class of concrete and the number of transverse reinforcement, these deformations did not stabilize and they collapsed in 6 ... 9 cycles from reaching fatigue strength or a possible decrease in their strength parameters due to statistical error in determining the breaking load of high levels.

The prototype fifth-series beams reinforced with external composite reinforcement deformed almost elastically until they reached their ultimate state in compressed concrete or stretched metal or composite reinforcement.

The presence of external carbon fiber reinforcement in the lower stretched zone of the beams in series 5 and on their supporting sections allows to increase their bearing capacity in comparison with similar series 3 beams at the same low-cycle load, on average, 1.7 times and partially change the nature of their destruction.
\end{abstract}

Keywords: concrete, fittings, carbon fiber cloth, reinforced concrete beam, deflections, deformations.

Introduction. In the course of operation or armed hostilities the span r/c. structures are subject to substantial damage and considerable reduction of their bearing capacity, especially under low-cycle repeated loading. In this connection it becomes necessary to renew their operation capacity and/or improve their bearing capacity. However, the current design standards contain no recommendations as to determination of the residual bearing capacity of such structures and calculation of their reinforcement. There are methods of the operation capacity renewal and 
reinforcement of the structures by increasing their sections adding metal or reinforced concrete elements. Still, the calculation methods of such reinforcement are also imperfect. It is proposed to renew operation capacity of such structures by strengthening their tensioned parts with CFRP; the performed experimental research will provide the basis for calculating bearing capacity of said structures with the aid of the deformation method improved by the authors.

Theoretical prerequisites. Resistance of $\mathrm{r} / \mathrm{c}$ elements to the combined action of transverse forces and bending moments at low-cycle non-reversal high-level loads is one of the most significant and underexplored problems both in the $\mathrm{r} / \mathrm{c}$ theory and in actual design process [1]. Indefinite repetition in operation and a change of the reverse load can lead to the consequences that are qualitatively different from those obtained as a result of calculation for permanent loading of maximum intensity which is, actually, is taken into account by the majority of the effective design standards.

While the current domestic and foreign national design standards specify the methods to calculate strength of oblique sections of span structures subject to permanent loading which are far from being perfect according to accuracy and reliability of the prediction even at permanent loading and which are far "behind" in this respect as compared with the calculation methods of the normal section strength, the impact of the infrequent cyclic non-reversal loading upon them is taken into account indirectly or is not accounted for at all, all the more if such loads are of high-level.

Analysis of recent research or publications. A survey of the available bibliography has proved that researchers still did not come to a single opinion about the impact of said loads on the bearing capacity of the studied elements. Majority of authors indicate that such bearing capacity reduces under low-cycle loading. Another researchers [2-4] state that the infrequent cyclic loading of the operational level $(n \leq 0.70)$ can lead to up to $20 \%$ higher strength of the span r/c elements, which needs additional clarifications and experimental confirmation.

Resistance of the span r/c CFRP-strengthened structures subject to low-cycle repeated highlevel loading that have been damaged in operation or in military hostilities was not studies at all. Therefore, the research along this line is important and up-to-date.

Purpose of work. It consists of studying the effect of concrete strength (class) on the strength, deformability and crack resistance of carbon reinforced concrete beams reinforced with carbon fiber, taking into account the influence of other structural factors, the magnitude and level of repeated low-cycle load of high levels with the improvement of the deformation method of their calculation and the development of analogues of calculation models of their tedious force resistance current loads, taking into account the physical nonlinearity of the materials used.

Research objectives. To adapt the methodology developed at the department using mathematical theory of experiment planning and existing equipment to perform systematic experimental studies of the effect of strength (class) of concrete on the basic performance parameters and the stress-deformation state of ordinary and beams reinforced with carbon fibre sheet. To reveal the features of the stress-strain state of single-span reinforced concrete beams reinforced with carbon fiber, and to test the effect of low-cycle repeated loading and to make a generalized assessment of the influence of this research factor on their bearing capacity. Experimentally check the possibility of engineering application of the most common normative and proprietary techniques for predicting the strength of conventional and strengthening reinforced concrete structures under the action of high-level cyclic loads. To improve the existing engineering methods for calculating the strength of the supporting sections, including inclined sections, of the specified beam structures, taking into account the action of the specified load.

Research methodology. In accordance with the adopted methodology the in-situ test is accomplished with the use of 4-factor 3-level $\mathrm{B}_{4}$ plan of Box-Behnken. The factors have been varied according to the data elicited from the literature review which shown that the most influential factor $\mathrm{X}_{1}$ is the value of the relative span of the section $\mathrm{a} / \mathrm{h}_{0}$, which was varied at three levels: $\mathrm{a}=$ $\mathrm{h}_{0}, 2 \mathrm{~h}_{0}$ and $3 \mathrm{~h}_{0}$. The next influential by value factor is, as a rule, such design factor as the grade of heavy concrete: $X_{2} \rightarrow \mathrm{C} 16 / 20, \mathrm{C} 30 / 35, \mathrm{C} 40 / 55$, and the third factor - the value (quantity) of the transverse reinforcement in the support areas: $X_{3} \rightarrow \rho_{w}=0.0016$; 0.0029; and 0.0044. The fourth factor was assumed to be the external action factor $X_{4}$ and a level of the reversal load: $\eta= \pm 0.50$;

Bulletin of Odessa State Academy of Civil Engineering and Architecture, 2020, no. 78, page 18-26 
$\pm 0.65 ; \pm 0.80$ of the actual bearing capacity, i.e., the transverse load value where at the opening width of the diagonal cracks ( $\mathrm{w}_{\mathrm{k}}$ exceeded $0.4 \mathrm{~mm}$, and the span sag $\mathrm{f} \geq 1 / 150$ ).

The tested beam samples were kept in normal thermal and humid conditions at the temperature $20 \pm 2^{\circ} \mathrm{C}$ and almost $100 \%$ air humidity during $100 \ldots 110$ days. Prior to testing the side surfaces of the beams were coated with a thin layer of lime solution in order to facilitate fixation of formation and development of normal and diagonal cracks, and afterwards these beams were dried until they reached the natural humidity.

Deformations of the concrete, reinforcement and bending of the test samples were measured with the help of dial indicators having a division value $0.001 \mathrm{~mm}$ and $0.01 \mathrm{~mm}$ accordingly.

The samples were tested according to the pattern of a single span simply supported beam which was intermittently loaded from the top and from the bottom by two point forces without any changes in the beam position.

Before the main experiment the 25 test beams (twin beams) of the first series were tested in turn for action of a single-time short-period stage-wise increasing loading, practically, up to destruction, when the open width of the diagonal cracks and the sag exceeded the permissible values $\left(\mathrm{w}_{\mathrm{k}}>0.8 \mathrm{~mm}\right.$, $\mathrm{f} \geq \mathrm{l} / 150$ ). Afterwards, the similar beams of the second and third series were tested subject to reversal and non-reversal low-cycle transverse loading of the defined levels according to the test assumption $\mathrm{N}$ $=20$ cycles; afterwards the sample was additionally loaded, practically, until destruction or achievement of the critical level, if that had not happened earlier during the previous cycles. Achievement of the critical values of deformation in concrete or reinforcement, excessively wide opening (to $1 \mathrm{~mm}$ ) of diagonal (more frequently) or normal (less frequently) cracks, substantial increase (to $15 \mathrm{~mm}$ ) of sags, and absence of increase or reduction (by 15\% and more) of the power plant pumping station pressure gauge were taken as the criteria of the test sample destruction. In the fourth series the tested sample beams of the 2nd series were brought to their limit state and then reinforced with a metal casing and tested by reversal and repeated loading.

After the tested samples of series 3 beams were brought to the limit state according to the 1 st and 2nd groups, the damaged lower tensioned zone and almost destructed support areas were strengthened with CFRP sheets Sika ${ }^{\circledR}$ Wrap ${ }^{\circledR}-231 \mathrm{C}$ according to the Sika Russie [5] technology (series 5). The construction of this strengthening is shown in Fig. 1.

The strengthened with external CFRP beams of series 5 were tested according to the same methodology as the beams of series 3 [6].

Research results. The tested beams of the 1st and 3rd series were designed so that their strength in the normal and oblique sections was almost similar, however, the destruction of the samples should have occurred in the relatively plain oblique sections at the final stage of their operation subject to the destructive transverse force and the associated bending moment with due account of the other external factors and design factors. The CFRP-strengthened large shear span beams failed in the normal sections within the "pure bend" zone, and the small shear span beams failed in the oblique compressed strips in the support zones [7].

The results of processing the obtained test data of the first, third and fifth series, removal of the insignificant coefficients and re-calculation of the remaining coefficients enabled, with the use of COMPEX software developed under guidance of Professor V.A. Voznesensky, to obtain the adequate mathematical models of strength i.e., the destructive transverse load $\mathrm{V}_{\mathrm{u}, \mathrm{i}}$ expressed in natural or reduced to the transverse section size expressions that contain sufficient information, display satisfactory convergence with the test data and characterize strength of the test elements:

- reference (series1) with the stage-wise gradually increasing loading:

$$
\begin{array}{r}
\hat{Y}\left(V_{u, 1}\right)=98-41 x_{1}+12 x_{2}+6 x_{3}+16 x_{1}^{2}-7 x_{2}^{2}-5 x_{3}^{2}-7 x_{1} x_{2}, \mathrm{\kappa H}, \mathrm{v}=5,2 \%, \\
\hat{Y}\left(\frac{V_{u, 1}}{b h_{0}}\right)=5,60-2,3 x_{1}+0,69 x_{2}+0,34 x_{3}+0,91 x_{1}^{2}-0,40 x_{2}^{2}-0,29 x_{3}^{2}-0,40 x_{1} x_{2},
\end{array}
$$

- similar beams (series 3) with the low-cycle non-reversal high-level loading:

$$
\hat{Y}\left(V_{u, 3}\right)=90-36 x_{1}+10 x_{2}+7 x_{3}-3 x_{4}+18 x_{1}^{2}-6 x_{2}^{2}-6 x_{3}^{2}-2 x_{4}^{2}-8 x_{1} x_{2}+2 \mathrm{x}_{1} \mathrm{x}_{4}, \mathrm{\kappa H}, \mathrm{v}=5,1 \%,
$$


$\hat{Y}\left(\frac{V_{u, 3}}{b h_{0}}\right)=5,14-2,06 x_{1}+0,57 x_{2}+0,40 x_{3}-0,17 x_{4}+1,03 x_{1}^{2}-0,34 x_{2}^{2}-0,34 x_{3}^{2}-0,11 x_{4}^{2}-0,46 x_{1} x_{2}$ $+0,11 \mathrm{x}_{1} \mathrm{x}_{4}, \mathrm{M \Pi \textrm {a }}$

- 3 CFRP-strengthened beams (series 5) brought to the critical state according to the 1 st group subject to similar loading:

$$
\begin{gathered}
\hat{Y}\left(V_{u, \mathrm{f}}\right)=153-69 x_{1}+12 x_{2}+4 x_{3}+9 x_{1}^{2}-8 x_{2}^{2}-7 x_{1} x_{2}, \\
\text { variability coefficient } \mho=5,2 \%, \\
\hat{Y}\left(\frac{V_{u, \mathrm{f}}}{b h_{0}}\right)=8,74-3,94 x_{1}+0,69 x_{2}+0,23 x_{3}-0,51 x_{1}^{2}-0,46 x_{2}-0,40 x_{1} x_{2}, \text { MПа. }
\end{gathered}
$$

a)
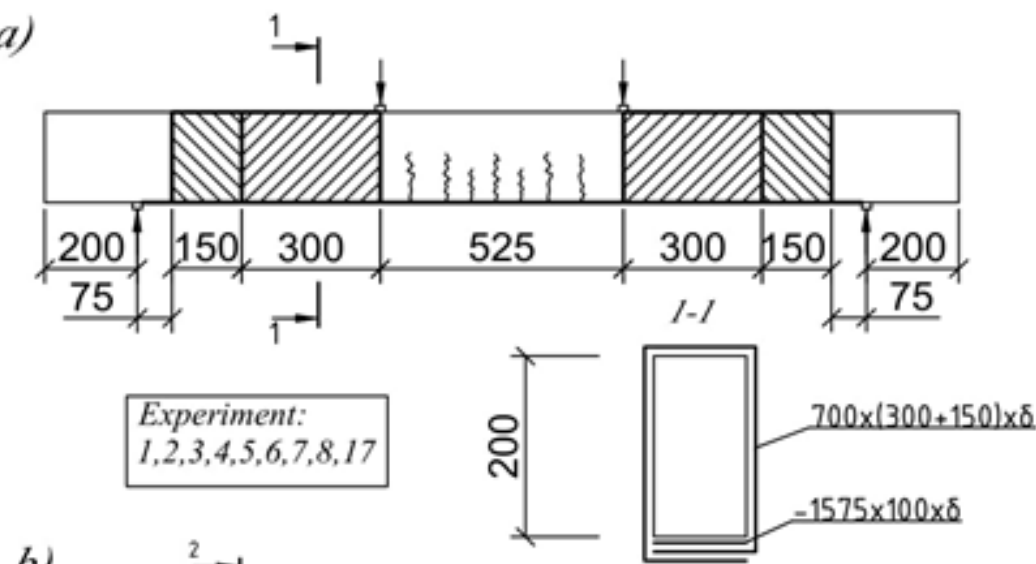

b) $\quad 2-1$

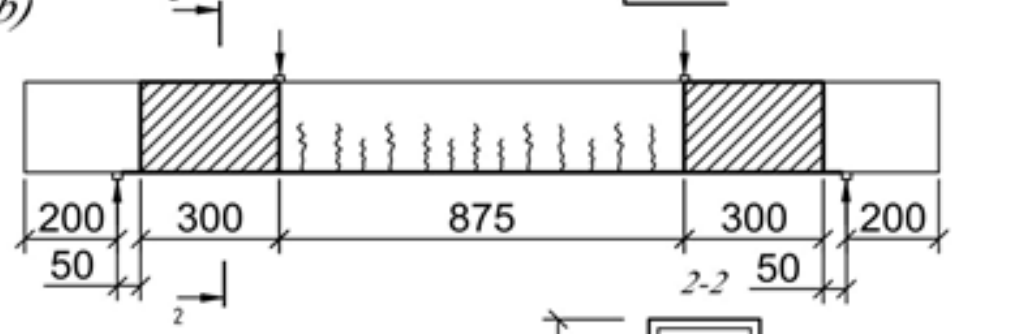

Experiment:

$19,20,21,22,23,24,25$

c)
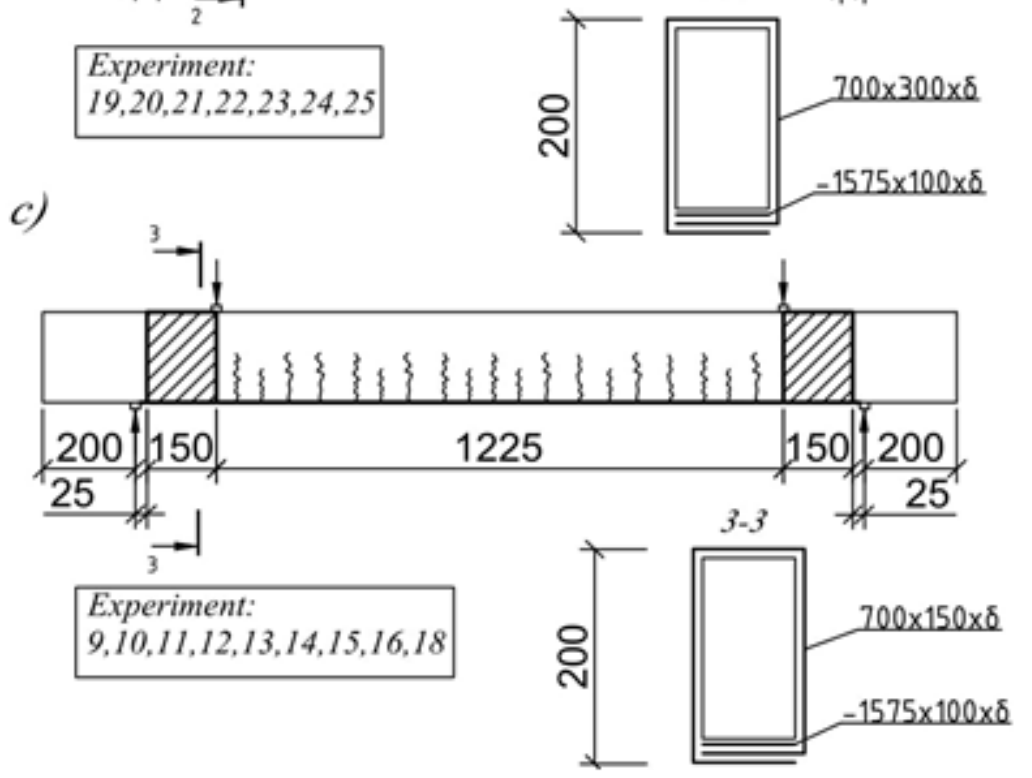

Fig. 1. Patterns of strengthening the lower tensioned zones and support areas of the damaged r/c beams of $3^{\text {rd }}$ series with large (a), medium (b) and small (c) shear spans 
Mathematical models (1), (2) and (3) characterize the bearing capacity of the tested elements support zones in the natural form, and (1a), (2a) and (3a) reflect the strength of their oblique sections reduced to the dimensions of their cross sections only.

The presented adequate mathematical models have essential advantage over other statistical dependencies because they allow of evaluating the impact of each studied factor on the output parameter not only individually but in their mutual interaction, as well as of comparing the value of such impact both in the individual series and in all indicated series together, i.e., to make a comprehensive analysis. Geometric interpretation of the actual and reduced bearing capacity of the tested beam sample support zones is partially shown in Fig. 2.

The concrete grade is the next factor according to the impact value. At that, as the grade improves from $\mathrm{C} 16 / 20$ to $\mathrm{C} 30 / 35$, the strength of oblique sections raises more intensively. With the upgrade of the concrete, from $\mathrm{C} 30 / 35$ to $\mathrm{C} 40 / 50$, the bearing capacity of the support zones changes slightly.
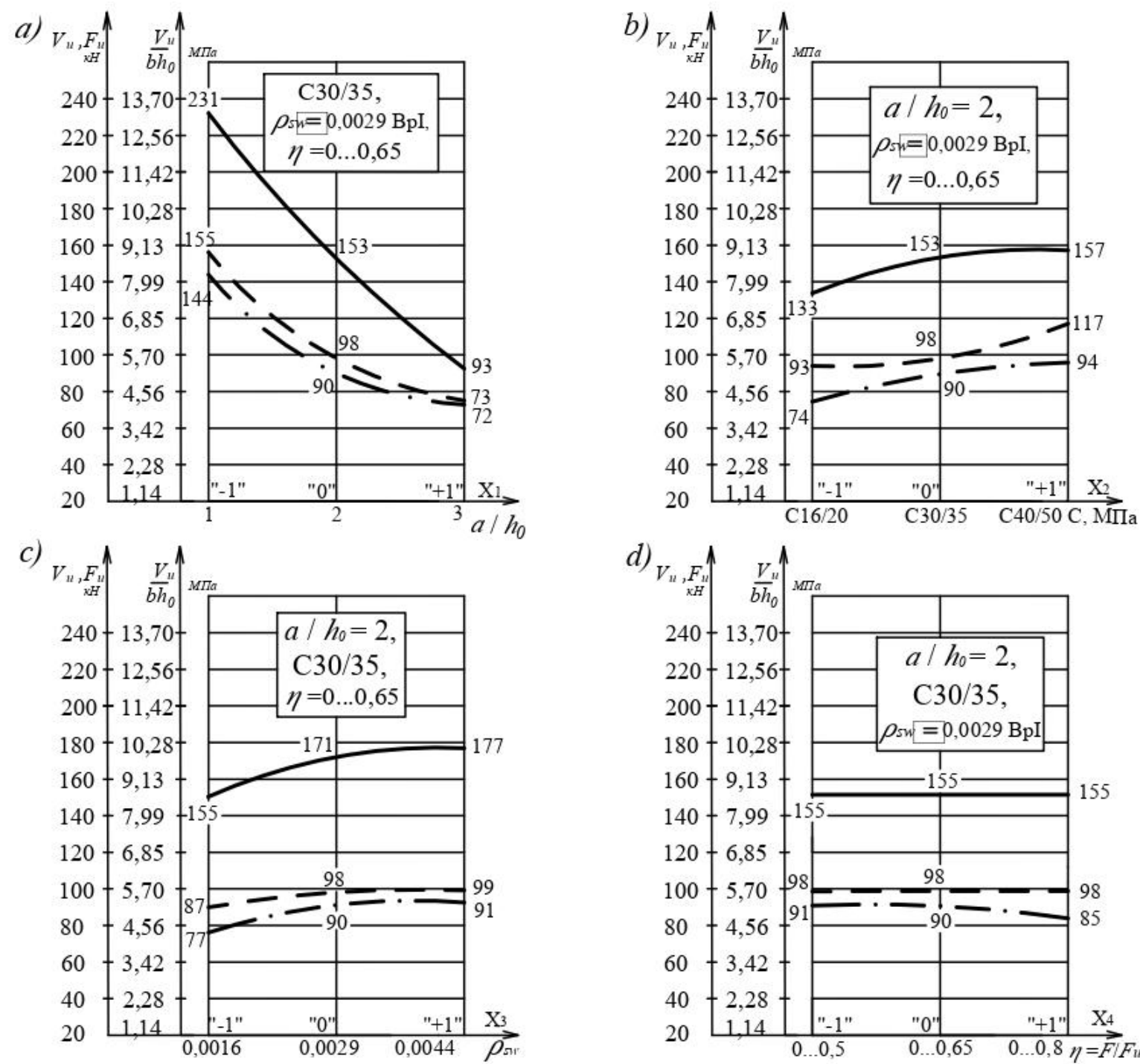

Conditional data designations:

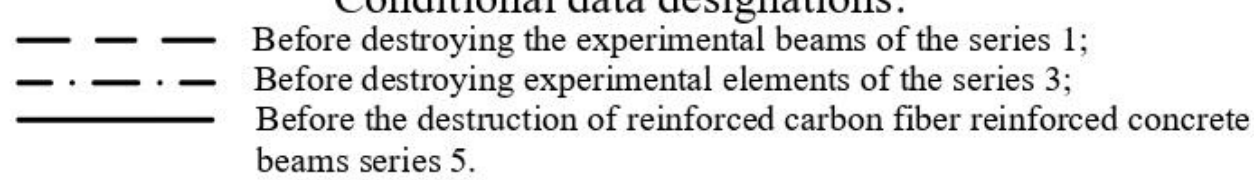

Fig .2. Destructive transverse force $\mathrm{Vu}$ or transverse loading $\left(\mathrm{F}_{\mathrm{u}}\right)$ of the tested sample beams prior to their failure vs the value of the relative shear span $a / h_{0}(a)$, concrete grade $C(b)$, quantity of the transverse reinforcement $\rho_{\mathrm{sw}}(\mathrm{c})$ and level of the low-cycle repeated loading $\eta(\mathrm{d})$ 
The similar pattern is observed with respect of the transverse reinforcement coefficient $\rho_{\mathrm{w}}$ when it changes from 0.0016 to 0.0044 .

Low-cycle loading and increase of the levels from 0.5 to 0.8 of the destructive load produces a negative effect on the test element bearing capacity.

As mathematical models (3) and (3a) show, the strength of the test $r / c$ beams damaged in the $3^{\text {rd }}$ series and later strengthened with carbon fibre in the $5^{\text {th }}$ series change in accordance with the same laws as in the previous series, however, with the considerable increase of strength.

As mathematical models (1) ...(3a) show, the natural average values of the destructive transverse force and their values reduced to the transverse section working area considerably differ within their series. If we take strengths of the tested sample beams of the first series that are single time stage-wise increasingly loaded equal to $100 \%$, then under low-cycle non-reversal loading in the third series the average bearing capacity of the oblique sections is reduced to $91.8 \%$, and that one which was CFRP-strengthened in the fifth series is increased, on the average, by $56 \%$.

Analysis of mathematical models (1) ...(3a) shows that they are of the same type by quality, and the impact of the design factors and external factors are similar by quality. The differences are in the quantitative indicators only. Thus, the strength of the oblique sections of the tested sample beams of the first, third and fifth series, that was reduced to working area of the transverse section, increases relative to their reduced average values 5.60; 5.14 and 8.74, accordingly:

- with reduction of the relative shear span $a / h_{0}$ from 3 to 1 in the indicated series by 84,80 and $90 \%$, accordingly;

- with the change of the concrete grade from C16/20 to C40/50 25, 22 and 16\%, accordingly;

- with the increase of the quantity of transverse reinforcement $\rho_{s w}$ from 0.0016 to 0.0044 by 12,16 and $5 \%$, accordingly;

- with reduction of the non-reversal loading $\eta$ from $0 \ldots 0.8$ to $0 \ldots 0.5$ in the third series;

- at single-time reduction of the relative shear span $a / h_{0}$ and increase of the concrete grade within the above indicated limits by $7 \%$ in the first, $9 \%$ in the third and $5 \%$ in the fifth series;

- with a single-time reduction of the relative shear span $a / h_{0}$ and a level of the non-reversal low-cycle loading in the third series.

The absolute majority of the tested beams of the first and third series failed in the oblique sections in two or one (more frequently) shear spans. The failure criteria of the tested samples were: achievement of the limit values of deformations in the concrete, reinforcement or external CFRPstrengthened beams exhibiting evident signs of plastic deformation, excessive opening (to $1 \mathrm{~mm}$ ) of the diagonal (more frequently) or normal (less frequently) cracks, considerable increase of sags $f \geq$ $0.01 \ldots 0.0067$ and absence of the increase or some decrease (to 15\%) of the power plant pumping station pressure gauge readings.

It is evident that the main cause of the bearing capacity reduction in low-cycle non-reversal loading lies in the structural disturbance of concrete, particularly in the support zones, its decompaction and partial loss of cohesion with the reinforcement.

The maximum growth of the residual deformations in concrete and transverse reinforcement of the tested beams of the first and third series was recorded during the first 2-3 cycles and, as a rule, they were stabilized before the fifth-sixth cycles at the loading levels $\eta=0 \ldots 0.50-0 \ldots 0.65$. In some samples made of the lowest concrete grade and the minimum transverse reinforcement at loading $\eta=0 \ldots 0.8$ these deformations did not stabilize and the samples failed in $6 \ldots 9$ cycles because of reaching the structural fatigue or due to possible reduction of their strength characteristics caused by a statistical error when determining the destructive high-level loads.

The tested sample beams of the fifth series that were strengthened with external composite reinforcement were deformed almost elastically until reaching the limit state in the compressed concrete or in the tensioned metal or composite reinforcement.

Not overreinforced $\left(\rho_{\mathrm{sw}} \leq 0.003(\mathrm{BpI}) ; \rho_{f} \leq 0.018\right.$ (A500C)) tested sample beams subject to a single-time static stage-wise increasing (first series) and low-cycle non-reversal (third series) loading failed, as a rule, according to $\mathrm{B} / \mathrm{M}$ pattern, i.e., in oblique sections and the prevailing action of the bending moment as a result of the longitudinal working reinforcement yield in the unsafe 
diagonal crack mouth and the transverse reinforcement that crosses such crack. As the quantity of the transverse reinforcement increases $\rho_{\mathrm{sw}} \geq 0.0044$, the similar test elements having medium $\left(\mathrm{a} / \mathrm{h}_{0}=2\right)$ and large $\left(\mathrm{a} / \mathrm{h}_{0}=3\right)$ shear spans failed according to $\mathrm{C} / \mathrm{V}$ pattern, i.e., in the diagonal crack under the prevailing action of the transverse force due to the transverse reinforcement yield and shear or bearing of the compressed zone of concrete above the top of unsafe diagonal crack; with the small shear spans $\left(\mathrm{a} / \mathrm{h}_{0} \leq 1\right)$ the similar test samples failed sometimes according to $\mathrm{D} / \mathrm{cm}$ pattern beyond the oblique compressed strip located between two diagonal cracks as a result of the concrete crush in this strip that follows the trajectory of the main compressing stresses.

Destruction of the normal sections of the test beam strengthened in the fifth series by CFRP [5] was accompanied, as a rule, by yield of the metal and composite structure, possible detachment of the protective concrete layer and breaking of the CFRP external reinforcement.

Destruction of the support zones of the fifth series beams that have small shear span also began from excessive deformation and detachment of the external composite reinforcement along with the protective concrete layer and crushing of concrete beyond the oblique compressed strip.

\section{Conclusions:}

1. Application of the mathematical theory of planning, adopted plan and levels of changing design factors and external impact factors make it possible to apply a system approach to analyse the events and compare the obtained data.

2. Peculiarities of the stress-strain state of the tested beam samples. Dependence of the nature and kind of their failure on the relevant ratio of the design factors and factors of external impacts, particularly presence and kind of external strengthening with composite materials was established for the first time ever.

3. Owing to the adopted methodology new experimental data was obtained in order to essentially specify physical models reflecting behaviour of oblique sections of the span r/c structures subject to high-level low-cycle repeated loading which resulted in description for the first time of the system impact of the shear span $\mathrm{a} / \mathrm{h}_{0}$, concrete grade $\mathrm{C}$, transverse reinforcement coefficient $\rho s w$ and level of repeated loading $\eta$ on crack resistance, deformability and strength of the tested beam samples.

4. Presence of the external carbon fibre-reinforced polymer strengthening in the lower tensioned zone of the beams in the 5th series and on their support zones makes it possible to enhance bearing capacity of the beams as compared with similar beams of the 3rd series, subjected to similar low-cycle loading, by 1.7 times on the average, and partially change the nature of their failure.

5. Increase of the shear span $\mathrm{a} / \mathrm{h}_{0}$ from 1 to 3 not only reduces by 2 and 2.5 times the destructive transverse low-cycle loading, accordingly, in common (series 3) and CFRP reinforced (series 5) r.c. beams but also defines the nature of such failure.

6. The performed research proved that upgrading concrete from $\mathrm{C} 16 / 20$ to $\mathrm{C} 40 / 50$ results in higher bearing capacity of the common beams of the 3rd series by $22 \%$ only, and in the carbonreinforced beams - by $15 \%$, because the tensile strength increase of the concrete "lags behind" the compression strength growth of the concrete when the concrete grade is upgraded.

7. Along with a greater quantity of transverse steel reinforcement from $\rho_{\mathrm{sw}}=0.0016$ to $\rho_{\mathrm{sw}}=0.0044$, the bearing capacity of common beams (series 3) is increasing in a non-linear way, same as the carbon-fibre strengthened elements (series 5), on the average by $15 \%$.

8. A change in the low-cycle transverse loading levels $\eta$ from $0 \ldots 0.5$ to $0 \ldots 0.8$ with the common beams (series 3 ) results in reduction of their bearing capacity by up to $10 \%$ while with the strengthened beams (series 5) their strength remains stable.

\section{References}

[1] Posobie no proektirovaniyu betonnyh i zhelezobetonnyh konstrukcij iz tyazhelogo betona bez predvaritel'nogo napryazheniya armatury (k SP 52-101-2003). Moskva, pp. 36-38, 2005.

[2] E.M. Babich, A.P. Pogorelyak, "Prochnost' betona posle dejstviya malociklovoj szhimayushchej nagruzki", Izv. vuzov. Ser. Stroitel'stvo i arhitektura, Moskva, no. 4, pp. 33-36, 1976. 
[3] E.M. Babich, O.M. Kuhnyuk, "Deformacijni harakteristiki betonu pri os'ovomu malociklovomu stisku", Visnik Rivnens'kogo derzhavnogo tekhnichnogo universitetu: zbirnik naukovih prac', Rivne, no. 2, pt. 3, pp. 21-25, 1999.

[4] E.M. Babich, Yu.A. Krus, Yu.N. Panchuk, "Rabota melkozernistogo betona v usloviyah malotsiklovogo staticheskogo nagruzheniya", Izv. vuzov. Ser. Stroitelstvo, no 9, pp. 26-32, 1995.

[5] STO 13613997-001-2011. Standart organizatsii. Usilenie zhelezobetonnyih konstruktsiy kompozitnyimi materialami SikaR. Moskva: OAO «TsNIIPromzdaniy», OOO «Zika». 2011.

[6] V. Karpiuk, A. Kostiuk, O. Maistrenko, Yu. Somina, "Influence of intermittent cyclic loading on reinforced concrete resistance model", Electronic journal of the faculty of civil engineering of Osijek, no 15, pp.59-74, 2017

[7] V.M. Karpyuk, Yu.A. SomIna, A.I. Kostyuk, O.F. Maystrenko, OsoblivostI napruzhennodeformovanogo stanu I rozrahunku zalIzobetonnih konstruktsIy za dIYi tsiklIchnogo navantazhennya visokih rIvnIv, Odessa, pp. 65-68, 2018.

\title{
МІЦНІСТЬ ЗВИЧАЙНИХ ТА ПОШКОДЖЕНИХ ЗАЛІЗОБЕТОННИХ БАЛОК, ПІДСИЛЕНИХ ВУГЛЕПЛАСТИКОМ, ЗА МАЛОЦИКЛОВОГО НАВАНТАЖЕННЯ ВИСОКИХ РІВНІВ
}

\author{
${ }^{1}$ Антонова Д. В., аспірантка, \\ antonova.dv@ukr.net, ORCID: 0000-0001-9021-857X \\ ${ }^{1}$ Карпюк В. М., д.Т.н., професор, \\ v.karpiuk@ukr.net, ORCID: 0000-0002-4088-6489 \\ ${ }_{1}^{1}$ Одеська державна академія будівниитва та архітектури \\ вул. Дідріхсона, 4, м. Одеса, 65029, Україна
}

\begin{abstract}
Анотація. Більшість прогінних залізобетонних конструкцій зазнають повторних навантажень різних за величиною і знаком, тобто складного напружено-деформаційного стану. В процесі експлуатації або в ході бойових дій прогінні залізобетонні конструкції зазнають значних пошкоджень i істотне зниження несучої здатності, особливо при дії малоциклового повторного навантаження. У зв'язку з цим виникає необхідність відновлення їх працездатності та / або збільшення несучої здатності.

У діючих нормах проектування відсутні рекомендації щодо визначення залишкової несучої здатності таких конструкцій і розрахунку їх посилення. Відомі способи відновлення працездатності та посилення конструкції за рахунок збільшення перерізу шляхом приєднання до них додаткових металевих або залізобетонних елементів. Але методики розрахунку такого посилення також недосконалі.
\end{abstract}

Відновлення роботи зазначених конструкцій пропонується здійснювати шляхом підсилення розтягнутих їх частин ФАП, а виконані експериментальні дослідження ляжуть в основу вдосконалення деформаційного методу розрахунку їх несучої здатності. Очевидно, що основною причиною зниження несучої здатності дослідних зразків при малоцикловому знакопостійному навантаженні $є$ порушення структури бетону, особливо на приопорних ділянках, його розущільнення і часткова втрата зчеплення з арматурою.

Найбільший приріст залишкових деформацій в бетоні і поперечній арматурі дослідних балок першої і третьої серій спостерігається на перших двох-трьох циклах i, як правило, вони стабілізуються до п'ятого-шостого циклу. А в деяких зразках з мінімальним класом бетону і кількістю поперечної арматури зазначені деформації не стабілізувалися і вони руйнувалися на 6 ... 9 циклах від досягнення втомної міцності або можливого зниження їх міцностних параметрів внаслідок статистичної похибки при визначенні руйнівного навантаження високих рівнів.

Дослідні зразки-балки п'ятої серії, посилені зовнішньої композитної арматурою, деформувалися майже пружно до настання граничного стану в стислому бетоні або розтягнутої металевої або композитної арматури.

Наявність зовнішньої вуглепластикової арматури в нижній розтягнутій зоні балок в серії 5 і на їх приопорних ділянках дозволяє підвищити їх несучу здатність у порівнянні 3 
аналогічними балками серії 3 при аналогічному малоцикловому навантаженні, в середньому, в 1,7 рази і частково змінити характер їх руйнування.

Ключові слова: бетон, арматура, вуглепластикове полотно, залізобетонна балка, прогини, деформації.

\title{
ПРОЧНОСТЬ ОБЫЧНЫХ И ПОВРЕЖДЕННЫХ ЖЕЛЕЗОБЕТОННЫХ БАЛОК, УСИЛЕННЫХ УГЛЕПЛАСТИКОМ, ПРИ ДЕЙСТВИИ МАЛОЦИКЛОВОЙ НАГРУЗКИ ВЫСОКИХ УРОВНЕЙ
}

\author{
${ }^{1}$ Антонова Д. В., аспирантка, \\ antonova.dv@ukr.net, ORCID: 0000-0001-9021-857X \\ ${ }^{1}$ Карпюк В. М., д.т.н., профессор, \\ v.karpiuk@ukr.net, ORCID: 0000-0002-4088-6489 \\ ${ }_{1}^{1}$ Одесская государственная академия строительства и архитектуры \\ ул. Дидрихсона, 4, г. Одесса, 65029, Украина
}

\begin{abstract}
Аннотация. Большинство пролетных железобетонных конструкций испытывают повторяющиеся нагрузки различные по величине и знаку, то есть сложного напряженнодеформационного состояния. В процессе эксплуатации или в ходе боевых действий пролетные железобетонные конструкции испытывают значительные повреждения и существенное снижение несущей способности, особенно при действии малоцикловой повторной нагрузки. В связи с этим возникает необходимость восстановления их работоспособности и/или увеличение несущей способности.

В действующих нормах проектирования отсутствуют рекомендации по определению остаточной несущей способности таких конструкций и расчета их усиления. Известны способы восстановления работоспособности и усиления конструкции за счет увеличения сечения путем присоединения к ним дополнительных металлических или железобетонных элементов. Но методики расчета такого усиления также несовершенны.

Восстановление работоспособности указанных конструкций предлагается осуществлять путем усиления растянутых их частей ФАП, а выполненные экспериментальные исследования лягут в основу совершенствования деформационного метода расчета их несущей способности. Очевидно, что основной причиной снижения несущей способности опытных образцов при малоцикловой знакопостоянной нагрузке является нарушение структуры бетона, особенно на приопорных участках, его разуплотнения и частичная потеря сцепления с арматурой.

Наибольший прирост остаточных деформаций в бетоне и поперечной арматуре исследовательских балок первой и третьей серий наблюдается на первых двух-трех циклах и, как правило, они стабилизируются до пятого-шестого цикла. А в некоторых образцах с минимальным классом бетона и количеством поперечной арматуры указанные деформации не стабилизировались и они разрушались на 6...9 циклах от достижения усталостной прочности или возможного снижения их прочностных параметров вследствие статистической погрешности при определении разрушающего нагрузки высоких уровней.

Опытные образцы-балки пятой серии, усиленные внешней композитной арматурой, деформировались почти упруго до наступления предельного состояния в сжатом бетоне или растянутой металлической или композитной арматуре.

Наличие внешней углепластиковой арматуры в нижней растянутой зоне балок в серии 5 и на их приопорных участках позволяет повысить их несущую способность по сравнению с аналогичными балками серии 3 при аналогичной малоцикловой нагрузке, в среднем, в 1,7 раза и частично изменить характер их разрушения.

Ключевые слова: бетон, арматура, углепластиковое полотно, железобетонная балка, прогибы, деформации.
\end{abstract}

Стаття надійшла до редакції 8.01.2020 